\title{
Influenza Virus Isolated in Thailand and Manila during the Period of August, 1979-August, 1981
}

\author{
Yukio YAMAZI, Yasuhiro SHIMIZU \\ Depertment of Microbiology and Immunology, \\ Nippon Medical School Tokyo \\ Yasue TAKEUCHI \\ Division of Virus and Rickettsia, National Institute \\ of Health, Tokyo \\ Kiyoaki SATSUTA, Masakazu TAKAHASHI, Izumi YOSHIKAWA, \\ Masanori NAGATA \\ Department of Hygiene and Public Health, \\ Nippon Medical School, Tokyo \\ Kampol PANASAMPOL, Vicharn VITHAYASAI, Jiraporn SUPAWADEE \\ Department of Microbiology, Faculty of Medicine, Chiang \\ Mai University, Chiang Mai \\ Boonyong PONGPROTE, Somboon SUPRASERT \\ Department of Preventive and Community Medicine, Faculty \\ of Medicine, Chiang Mai University, Chiang Mai \\ Damri DAMRONSAK \\ Department of Pediatrics, Faculty of Medicine, Chiang Mai \\ University, Chiang Mai \\ Prasong TUCHINDA, Sombodhi BUKKAVESA \\ Department of Pediatrics, Siriraj Hospital, \\ Mahidol University, Bangkok \\ Prasert THONGCHAROEN \\ Department of Virology, Siriraj Hospital, \\ Mahidol University, Bangkok \\ Kanai CHATIYANONDA \\ Virus Research Institute, Ministry of Public Health, Bangkok
}

(Received 10 June 1982/Accepted 14 September 1982)

Key words : Influenza virus, Thailand, Infection South-East Asia, Epidemiology

\section{Summary}

One hundred and thirty-six strains of influenza viruses isolated from patients in Thailand and Manila during the period of August, 1979-August, 1981 were studied by hemagglutination inhibition reaction with postinfection ferret sera. The Hong Kong subtype (H3N2) was prevalent in Thailand and Manila in the rainy season of 1980, while the USSR subtype (H1N1) was prevalent in Thailand in 1981. A/USSR/92/77- and A/Brazil/11/78-like viruses (H1N1) seemed to have circulated for longer period than in Japan.

別刷請求先：（采113）文京区千駄木1-1-5 日本医科大学微生物学免疫学教室 山地 幸雄 
Two strains of a new variant of Hong Kong subtype (H3N2), A/Kyoto/C-1/81-like virus, were first isolated in Bangkok in August, 1980. These variant strains of H3N2 were again isolated in Bangkok in January and August of 1981. Twelve strains of type B virus, isolated in Thailand and in Manila since May, 1980 were similar to those isolated in Japan during the same period, and the isolation of a new variant, B/Shiga/75/81-like virus, in Thailand was about 6 months after the isolation in Japan.

\section{Introduction}

It is difficult to explain the epidemic behavior of influenza on a simple model, like that of measles. The main features giving rise to epidemiological difficulties are (1) seasonal occurrence, (2) antigenic drift of virus, (3) antigenic shift of virus, and (4) world-wide distribution of influenza at all inhabited areas, in all climates, and in persons of all ages. Seasonal occurrence, so regular and familiar that it tends to be taken for granted, can be followed on a global scale in succesive issues of the Weekly Epidemiological Record of the World Health Organization, in which influenza epidemics appear to be travelling to and fro across the world almost annually. Season rather than climate is their determinant as shown by seasonal epidemics of influenza in the temperate zones during the winter seasons and in the tropics during the rainy seasons of monsoons ${ }^{1}$. In the latter zone, the mean monthly temperature and sometimes humidity may vary only a little throughout the year. One hypothesis, dealing with the epidemiology of influenza virus, proposes the temperate epidemic zone and the tropical virus-reservoir $z e^{2) 33}$. Japan may be included in the former, while South-East (SE) Asia and the Tropical Western Pacific in the latter. This hypothesis is seemingly supported by the following facts: (1) the yearly occurrence of influenza alternates between these two zones (mainly in November-April in Japan, and April-November in SE Asia and the Tropical Western Pacific) ${ }^{1)}$; (2) in SE Asia, the number of reported cases does not fall much from the rainy season (June-October) to the dry season (December-April) ${ }^{1)} ;(3)$ some variants of the virus have been isolated in SE Asia and in the Philippines several months prior to their isolation in $\operatorname{Japan}^{4) \sim 6)}$.

Influenza is, however, ubiquitous on the earth. In the late 20th century when the transportation system has been greatly developed, it would be myopic to visualize influenza virus movement as occurring only between Japan and SE Asia as well as the Tropical Western Pacific. The routes by which the virus can enter either area are multiple. In addition, Hope-Simpson ${ }^{7}$ presented a hypothesis from the household surveylance in England that the initiating factor of influenza A epidemics is an activation of the latent virus in humans, though any direct evidence of the latent virus was not presented.

Thus, it is important to be aware of the kinds of isolates that are isolated throughout SE Asia, the Tropical Western Pacific and Japan so that hopefully some epidemiological and virological inferences can be drawn. In this study, 136 strains of influenza virus fror patients in Thailand and Manila during the period of August, 1979-August 1981 were evaluated by HI test.

\section{Materials and Methods}

The Society for Medical Research in South-East Asia, Nippon Medical School, Tokyo, dispatched research teams to Thailand in August 1979, May and August 1980, December 1980-January 1981, and August 1981, and to Manila in May and August 1980 and January 1981. They collected 996 throat swab specimens from patients suspected of having influenza through the cooperation of the Faculty of Medicine, Chiang Mai University, the Siriraj Hospital, Mahidol University, and the Virus Research Institute, Bangkok, and the San Lazaro Hospital, Manila. The specimens were placed in nutrient broth and kept at $-70^{\circ} \mathrm{C}$ on dry ice before being inoculated into developing hens' eggs in the laboratories of Nippon Medical School, and of the National Institute of Health, Tokyo.

Isolation of virus was performed with the amniotic inoculation of $0.2 \mathrm{ml}$ of the clinical specimen into 10 days old eggs, and the HI tests with chicken erythrocytes ${ }^{8)}$ were performed after 2 or less passages through the eggs. Reference, postinfection, ferret antisera were raised against the following strains : A/USSR/92/77, A/Brazil/11/78, A/Kumamoto/37/79, A/England/403/80, and A/Fukuoka/C-1/81 of H1N1; A/Kumamoto/22/76, A/Tokyo/1/77, A/Bangkok/1/79, A/Aichi/1/80, A/Bangkok/137/80, A/ Bangkok/211/81, A/Kyoto/C-1/81, and A/Niigata/102/81 of H3N2; and B/Kanagawa/3/76, B/Sin- 
Table 1 Isolation of influenza viruses in

Thailand and in Manila, August 1979-

August 1981

\begin{tabular}{llccc}
\hline $\begin{array}{l}\text { Date of } \\
\text { collecting } \\
\text { specimens }\end{array}$ & \multicolumn{1}{c}{ Areas } & \multicolumn{3}{c}{ Viruses } \\
\hline Aug. 20-23, '79 & Chiang Mai & 6 & 2 & 0 \\
Aug. -Sep. '79 & Bangkok & 0 & 2 & 0 \\
May 13-20, '80 & Chiang Mai & 2 & 0 & 0 \\
May 11-20, '80 & Sakaeo & 3 & 1 & 0 \\
May 11-22, '80 & Bangkok & 1 & 7 & 0 \\
May 27-30, '80 & Manila & 0 & 12 & 2 \\
June-Aug. '80 & Bangkok & 0 & 25 & 1 \\
Aug. 18-22, '80 & Chiang Mai & 0 & 14 & 2 \\
Aug. -Sep. '80 & Bangkok & 0 & 17 & 1 \\
Oct. '80 & Bangkok & 0 & 2 & 0 \\
Jan. '81 & Bangkok & 2 & 1 & 0 \\
June-Aug. '81 & Bangkok & 11 & 1 & 1 \\
Aug. 17-25, '81 & Chiang Mai & 15 & 0 & 5 \\
\hline \multicolumn{1}{c}{ Subtotal } & & 40 & 84 & 12 \\
\hline \multicolumn{1}{c}{ Total } & & & 136 & \\
\hline
\end{tabular}

Virus strains comprised 78 isolated in Japanese laboratories from 996 throat swabs, and 58 isolated in the Siriraj Hospital and the Virus Research Institute,

Bangkok

gapore/222/79, and B/Shiga/75/81 of type B.

Virus strains studied in this paper comprise 78 strains isolated in Japanese laboratories from aforesaid 996 throat swabs, and 58 strains isolated in the laboratories of the Virus Research Institute and of the Siriraj Hospital, Bangkok.

\section{Results}

Isolation of viruses. The virus strains isolated in this study are listed in Table 1. It is comprised of 40 strains of $\mathrm{H} 1 \mathrm{~N} 1,84$ of $\mathrm{H} 3 \mathrm{~N} 2$ and 12 of type $\mathrm{B}$ virus. H3N2 seemed to prevail during the rainy season of 1980, and H1N1 during the rainy season of 1981.

H1N1 viruses isolated in Thailand. Forty strains of H1N1 virus were isolated in Thailand during the period of August, 1979-August, 1981. The H1N1 virus was not obtained from Manila. Antigenic properties of the 40 strains as determined with HI tests are summarized in Table 2. All 6 of the 1979 isolates were A/USSR/92/77-like viruses. Five out of 6 of the May, 1980 isolates were related to the $\mathrm{A} / \mathrm{Brazil} / 11 / 78$ virus, while the sixth was not similar to any of the reference viruses. Three out of 1 3 isolates from Bangkok in 1981 were similar to $\mathrm{A} / \mathrm{Brazil} / 11 / 78$, while the other 10 were intermediate between the Brazil-variant and A/England/403/80. Nine out of 15 strains isolated from Chiang Mai in August, 1981 were similar to the Brazil-variant, 5 were intermediate between Brazil and Englandvariants, and one was similar to the $\mathrm{A} /$ England/403/80. This data suggests that in Thailand the antigenic properties of H1N1 viruses drifted from USSR-like variant, through the Brazil-like variant, to the England-like variant during the period of August, 1979-August, 1981

H3N2 viruses isolated in Thailand and in Manila. Eighty-four strains of H3N2 virus were isolated during the period of August, 1979-August, 1981, Table 3 summarizes the antigenic properties of 75 of these isolates studied with $\mathrm{HI}$ reactions. Two strains isolated in Chiang Mai in August, 1979 were similar to A/Tokyo/1/77 (equivalent to A/Texas/1/77), while 2 strains isolated in Bangkok in 1979 were $\mathrm{A} /$ Bangkok/1/79 and 2/79. Among 67 strains isolated from Thailand and Manila during the period of 
Table 2 Antigenic properties of AH1 viruses isolated in Thailand.

August 1979-August 1981

\begin{tabular}{|c|c|c|c|c|c|c|c|}
\hline \multirow{2}{*}{$\begin{array}{l}\text { Month of } \\
\text { collecting } \\
\text { specimens }\end{array}$} & \multirow[b]{2}{*}{ Areas } & \multicolumn{4}{|c|}{ Antigenic similarity } & \multirow[b]{2}{*}{ England $^{\text {c) }}$} & \multirow[b]{2}{*}{ ? } \\
\hline & & $\mathrm{USSR}^{\mathrm{a})}$ & $\begin{array}{l}\text { USSR- } \\
\text { Brazil }\end{array}$ & Brazilb) & $\begin{array}{l}\text { Brazil- } \\
\text { England }\end{array}$ & & \\
\hline Aug. '79 & Chiang Mai & 6 & 0 & 0 & 0 & 0 & 0 \\
\hline May '80 & Thailand & 0 & 2 & 3 & 0 & 0 & 1 \\
\hline Jan. ' 81 & Bangkok & 0 & 0 & 0 & 2 & 0 & 0 \\
\hline June-Aug. '81 & Bangkok & 0 & 0 & 3 & 8 & 0 & 0 \\
\hline Aug. ' 81 & Chiang Mai & 0 & 0 & 9 & 5 & 1 & 0 \\
\hline
\end{tabular}

a) $\mathrm{A} / \mathrm{USSR} / 92 / 77$. b) $\mathrm{A} /$ Brazil/11/78. c) A/England $/ 403 / 80$.

Table 3 Antigenic properties of AH3 viruses isolated in Thailand and Manila. August 1979-August 1981

\begin{tabular}{llccccc}
\hline \multicolumn{1}{c}{$\begin{array}{c}\text { Month of } \\
\text { collecting } \\
\text { specimens }\end{array}$} & \multicolumn{1}{c}{ Areas } & Tokyo $^{\text {a) }}$ & $\begin{array}{c}\text { Tokyo- } \\
\text { Bangkok }\end{array}$ & Bangkok $^{\text {b) }}$ & Kyoto $^{\text {c) }}$ & ? \\
\cline { 2 - 7 } & & 2 & 0 & 1 & 0 & 1 \\
\hline Aug. -Sep. '79 & Thailand & 16 & 29 & 14 & 2 & 6 \\
May-Aug. '80 & Thailand and Manila & 0 & 0 & 2 & 1 & 0 \\
Oct. '80-Jan. '81 & Bangkok & 0 & 0 & 0 & 1 & 0 \\
Aug. '81 & Bangkok &
\end{tabular}

a) A/Tokyo/1/77. b) A/Bangkok/1/79. c) A/Kyoto/C-1/81.

May-August, 1980, 16 were similar to A/Tokyo/1/77, 29 were intermediate between A/Tokyo/1/77 and $\mathrm{A} /$ Bangkok/1/79, and 14 were similar to $\mathrm{A} /$ Bangkok/1/79. However, the other 8 strains were different from both of these referense viruses. Two strains isolated in October, 1980 were A/Bangkok/1/79-like viruses. Both of 2 strains isolated in January and August 1981 were different from both $\mathrm{A} / \mathrm{Tokyo} / 1 /$ 77 and A/Bangkok/1/79.

Type B influenza viruses isolated in Thailand and Manila. Twelve strains of type B virus were isolated after May, 1980 in this study, and 5 out of 12 were from Chiang Mai in August, 1981. All of the 12 strains were similar to either B/Kanagawa/3/76, B/Singapore/222/79, or B/Shiga/75/81. B/ Shiga/75/81-like virus was isolated in Bangkok in August, 1981.

\section{Discussion}

In order to study prevailing viruses in SE Asia and the Tropical Western Pacific, and to know their relationship to Japanese isolates, we tested 136 influenza virus strains isolated from patients in Thailand and Manila during the period of August, 1979, to August, 1981. Hemagglutination inhibition (HI) reactions were determined, using post-infection ferret antisera, which had been raised to a number of referenece strains.

In August, 1979, both of H1N1 and H3N2 viruses were isolated in Chiang Mai. During the period of October, 1978-September, 1979, the H3N2 virus was isolated only in a few countries in the world ${ }^{12)}$, and it was not reported in Japan ${ }^{13)}$. Isolation of H3N2 virus in Chiang Mai, and in Bangkok in AugustSeptember, 1979, is evidence of the smouldering of the subtype in Thailand.

H3N2 virus was prevalent in both Thailand and Manila in the rainy season of 1980, and H1N1 was prevalent in Thailand in the rainy season of 1981. In Japan, the influenza virus isolates were: H1N1 1420, H3N2 619 and B 279 in the winter of 1979-1980 ; and H1N1 718, H3N2 150, and B 232 in the winter of 1980-1981914) ; and B was prevailing in 1981-1982. In USA, the influenza virus isolates were H1N1 24, H3N2 0, and B 1334 in the winter of 1979 ; and H3N2 was more prevalent than H1N1 in the winter of 1980-19815). Thus, different subtypes or types prevailed in the different parts of the world. However, the prevalence of a particular subtype or type was much greater in Thailand and in USA than in Japan. 
This might reflect the difference of the vaccination policy. In Thailand, the vaccine is not given, and in the USA, it is recommended only to high risk groups. But in Japan, more than $50 \%$ of school children are immunized with trivalent $(\mathrm{H} 1 \mathrm{~N} 1, \mathrm{H} 3 \mathrm{~N} 2$, and $\mathrm{B})$ vaccine. The immunity of people is a major factor in both of the direct spread-hypothesis and the latent virus-hypothesis ${ }^{7}$ of influenza epidemics, as far as the selection of the prevailing virus concerns. If we have a casual speculation, development and spread of the prevailing virus may be inhibited by the level of immunity in school children, and any particular subtype or type of virus may not become exclusively prevalent in Japan. But in Thailand and USA, different subtype and type could prevail alternately in the successive year without the interference by the level of immunities raised by the large scale administration of the trivalent vaccine, where the immunity has been mainly acquired with the natural infection the year before.

In Japan, most H1N1 isolated in the winter of 1979-1980, and of 1980-1981, were similar to A/Brazil/ $11 / 78$ or $\mathrm{A} /$ Kumamoto $/ 37 / 79^{13}$. Only the $\mathrm{A} /$ Fukuoka/C-1/81-like viruses, which have drifted more than A/England/403/80, were found after December, 1981. The H1N1 viruses isolated from Thailand in 1979 were the USSR-like viruses, 2 (from Sakaeo) out of 6 strains in 1980 were related to the USSR-variant, and 9 out of 15 isolates from Chiang Mai in 1981 were the Brazil-variants. These results sugget that the old USSR-variant and the Brazil-variant survived and circulated for a longer period in Thailand than in Japan. Studies of the recombinant H1N1 viruses that had received genes from the H3N2 variant ${ }^{16) 17}$ ) are not included in this report.

Isolation of antigenically drifted strains of $\mathrm{H} 3 \mathrm{~N} 2$ viruses in Thailand and Manila seemed more frequent than in case of H1N1. In addition, the study of H3N2 viruses isolated in Thailand gave this interesting result : that 2 strains of a new variant of $\mathrm{A} / \mathrm{Kyoto} / \mathrm{C}-1 / 81$-like virus ${ }^{6 / 9)}$ appeared at Bangkok in August, 1980, 6 months prior to the isolation in Japan, and the variant viruses were again isolated in that city in January and August, 1981. Details of this story will be described in further reports ${ }^{10111}$. It is not known, however, whether the new variant strains developed independently in Thailand and in Japan according to the latent virus-hypothesis ${ }^{7}$, or traveled to and fro in the areas including SE Asia and Japan by the direct spread among people.

All of the 12 sprains of type B virus isolated from Thailand and Manila since May, 1980 were not different from the viruses isolated in Japan during the same period. Isolation of the type B virus was frequent in Chiang Mai in the late stage of this study, because $25 \%$ of influenza virus strains in the area in August, 1981 were type B. One strain from Bangkok in August, 1981 was similar to the new variant, $\mathrm{B} /$ Shiga/75/81 which was first isolated in Japan in the early winter of $1981^{9}$. Thus, the variant appeared in Japan prior to the isolation in Thailand.

Both of the new variants, $\mathrm{A} / \mathrm{Kyoto} / \mathrm{C}-1 / 81$ - and $\mathrm{B} / \mathrm{Shiga} / 75 / 81$-like viruses, were isolated from Bangkok, but not from Chiang Mai. This might suggest a difference between Bangkok and Chiang Mai, as far as the apparent circulation of new variants in SE Asia and Japan concerns.

This study was supported in part by research grants from the Ministry of Education, Tokyo, \#504164 in 1980 and \#56043057 in 1981 ; from the International Medical Foundation of Japan, Tokyo in 1979-1981; and from the Society for the Medical Research in South-East Asia, Nippon Medical School, Tokyo in 1979-1981. Please address request for reprints to Dr. Yukio Yamazi, Dept. of Microbiol. and Immunol., Nippon Medical School, 1-1 Sendagi, Bunkyo-ku, Tokyo, Japan 113.

\section{References}

1) Takahashi, M., Takeuchi, Y., Yoshikawa, I., Shimizu, Y., Satsuta, K., Noriki, H. \& Yamazi, Y. : Influenza in South-East Asia. J. Nippon Med. Sch., 48: 455-457, 1981.

2) Fukumi, H.: Ecological analysis of the epidemics, In Noriki and Kaji (ed), "Advances of Influenza Research: Pathogensis, Epidemics and Vaccine," Kindai Shuppan, Tokyo, 1977, p. 30-48.

3) Fukumi, H.: "Influenza," Shinjuku Shobo, Tokyo, 1976, p. 169-172.

4) Fukumi, H. \& Takeuchi, Y.: Antigenic analysis of influenza viruses in 1975-1976. "Report from the 15th Meeting of the Society for Influenza Vaccine Research", Assoc. Biol. Manufact.Japan, Tokyo, 1977, p. 101-105. 
5) Fukumi, H., Takeuchi, Y., Ishida, M., Nakayama, M., Nerome, K. \& Saito, T. : Epidemiology and virus types of influenza in this year. "Report from the 12th Meeting of the Society for Influenza Vaccine Research", Assoc. Biol. Manufact. Japan, Tokyo, 1974, p. 67-74.

6) Yamazi, Y., Takeuchi, Y., Satsuta, K., Sugiyama, T., Takahashi, M., Yoshikawa, I., Shimizu, Y., Nagata, M., Oya, A., Noriki, H., Vithayasai, V., Damronsak, D., Thongcharoen, P., Chatiyanonda, k. \& Tuchinda, P. : Influenza viruses isolated in South-East Asia during the period of August 1979-January 1981. J. Nippon Med. Sch. , $49: 767-780,1982$.

7) Hope-Simpson, R. E. : Epidemic mechanisms of type A influenza. J. Hyg., Camb., 83 : 11-26, 1979

8) Yamazi, Y. \& Yoshida, K.: "Testbook of Laboratory Works of Microbiology and Immunology", Igaku Shuppan Sha, Tokyo, 1979, p. 120-123.

9) Takeuchi, Y., Oya, A. \& Satsuta, K. : Laboratory-based surveilance of influenza virus in Japan during the winter of 1980-1981. J. Japan. Assoc. Infect. Dis., 56 : 182-192, 1982.

10) Takeuchi, Y., Satsuta, K., Yamazi, Y., Yoshikawa, I., Nagata, M., Yunoki, H., Watari, E., Suzuki, H., Suprasert, S., Pongprote, B., Vithayasai, V., Supawadee, J., Damronsak, D., Prathnadi, P., Tuchinda, P., Chearskul, S., Thongcharoen, P., Chatiyanonda, K., \& Kupradinunt, S.: Isolation of influenza viruses in Thailand during June-August 1981. J. Nippon Med. Sch., 49: 438-441, 1982.

11) Takeuchi, Y., Satsuta, K., Yamazi, Y., Takahashi, M., Prathnadi, P., Supawadee, J., Suprasert, S., Thongcharoen, P. \& Chatiyanonda, K. : Antigenic analysis of influenza viruses isolated in Thailand, June-August 1981. J. Nippon Med. Sch., 49: 442-445, 1982.

12) World Health Organization: Influenza in the world, October 1978-September 1979. Wkly Epidem. Rec. WHO., $55:$ 17-20, 1980.

13) Takeuchi, Y.: Epidemics of influenza in 1979-1980. "Report from the 18th Meeting of the Society for Influenza Vaccine Research", Assoc. Biol. Manufact. Japan, Tokyo, 1980, p. 97-106.

14) Takeuchi, Y. : Influenza vaccine. Rinsho to Kenkyu (Clinic and Research), 58 : 3895-3903,, 1981.

15) Kendal, A. P. : Personal communication to the NIH, Tokyo, 1981.

16) Nakajima, S., Nakajima, K., Takeuchi, Y. \& Sugiura, A. : Influenza surveylance based on oligonucleotide mapping of RNA of H1N1 viruses prevalent in Japan. 1978-1979. J. Infect. Dis., 142: 492-502, 1980.

17) Young, J. F. \& Palese, P.: Evolution of human influenza viruses in nature : Recombination contributes to genetic variation of H1N1 strains. Proc. Natl. Acad. Sci. U. S. A., 76: 6547-6551, 1979.

\section{9年 8 月～1981年 8 月にタイ国拉よび}

$$
\text { マニラで分離されたインフルエンザウイルス }
$$

$$
\begin{aligned}
& \text { 日本医科大学微生物学免疫学教室 } \\
& \text { 山地幸雄清水康弘 } \\
& \text { 国立予防衛生研究所ウイルス・リケッチア部 } \\
& \text { 武内安恵 } \\
& \text { 日本医科大学衛生学公衆衛生学教室 } \\
& \text { 薩田 清明 高橋 修和 吉川泉 長田 正憲 } \\
& \text { チェンマイ大学医学部微生物学教室 } \\
& \text { カンポール・パナスアンポール } \\
& \text { ウイチヤン・ウイタヤセイ } \\
& \text { ジラポン・スパワデイ } \\
& \text { チェンマイ大学医学部予防医学社会医学教室 } \\
& \text { ブニヨン・ポンプローテ・ソンブン・スプラサート } \\
& \text { チェンマイ大学医学部小児科 } \\
& \text { ダムリ・ダムロンサク }
\end{aligned}
$$




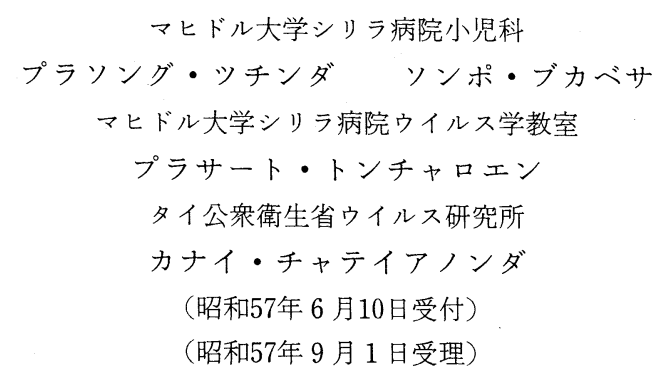

1979年 8 月から1981年 8 月までにタイ国抢よびマニラの患者から分離された136株のインフルエンザウイル スの抗原分析を, 感染フェレット血清を用いる HI 試験により行なった。 1980年の雨季のタイおよびマニラで は，主に H3N2が流行し，1981年のタイでは，主にH1N1が流行した。 A/USSR/92/77掞よび A/Brazil/11/78 様ウイルスは, タイでは日本より長期間存続した. N3N2 の新しい变異ウイルス, A/京都/C-1/81様ウイルスは, 日本より 6 ケ月先立って, 1980年 8 月にバンコックではじめて分離され, 1981年 1 月および 8 月に再びバン コックで分離された。B型は，1980年以降にタイ国およびマニラで分離され，それらは同じ時期の日本分離株 と同様であり, 新しい変異ウイルス, B/志賀/ $75 / 81$ 様ウイルスは, タイ国では日本より約 6 ケ月抢くれて分離 された。 